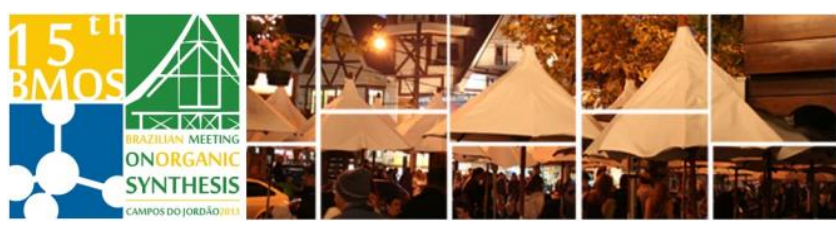

\title{
Synthesis of 3,4-dibromo-1 H-pyrrole-2-carbaldehyde: a building block for preparation of tetrabromobacteriochlorins
}

\section{Francisco F. de Assis, Timothy J. Brocksom and Kleber T. de Oliveira.*}

Universidade Federal de São Carlos - UFSCar, Departamento de Química,13565-905, São Carlos, SP,

Brazil.

*e-mail: kleber.oliveira@ufscar.br; www.lqbo.ufscar.br

Keywords: Pyrroles, building blocks, bacteriochlorins.

\section{INTRODUCTION}

Bacteriochlorins are porphyrin derivatives in which two of the double bonds of the porphyrin ring system have been reduced (Figure 1).

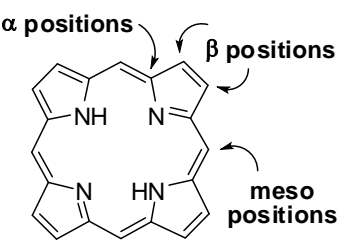

Porphyrin

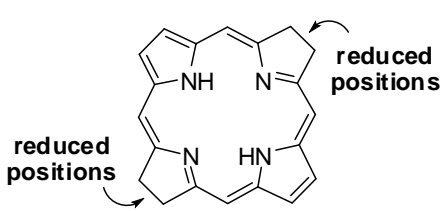

Bactereochlorin
Figure 1. Porphyrin and bacteriochlorin core structures.

The bacteriochlorins have found many applications in photomedicine and materials science. ${ }^{1,2}$ The synthesis of these compounds represents a challenge due to the tendency to re-oxidize back to the corresponding chlorin or porphyrin. Problems of separation and purification are also common due to the formation of complex mixtures. Lindsey's group has developed an efficient approach to synthesize stable substituted bacteriochlorins, without formation of complex product mixtures. ${ }^{3}$ In this work, we describe the synthesis of a suitably functionalized pyrrole, which is to be used as a building block for the synthesis of bacteriochlorins, through Lindsey's methodology.

\section{RESULTS AND DISCUSSION}

Initially we have performed the formylation at the $\alpha$ position of pyrrole 1, using $\mathrm{POCl}_{3} / \mathrm{DMF}$ in 1,2dichloroethane at reflux (Scheme 1). Compound 2 was obtained in $81 \%$ yield and reduced to pyrrole 3 under the Wolf-Kishner conditions (84\%). Protection with triisopropylsilyl chloride (TIPSCI) in THF and $n$ BuLi at $-78^{\circ} \mathrm{C}$ led to compound 4 in $46 \%$ yield. A selective bromination at the $\beta$ positions of the pyrrolic ring 4 using NBS in THF at $-78^{\circ} \mathrm{C}$ furnished pyrrole 5 in $58 \%$ yield. As the final step to make the desired compound, an oxidation/deprotection reaction using ceric ammonium nitrate (CAN) was carried out. The 3,4-dibromo-1H-pyrrole-2carbaldehyde (6) was obtained in $28 \%$ yield in a test reaction, and currently we are investigating some improvements in this last transformation to invest efforts for the synthesis of 7.
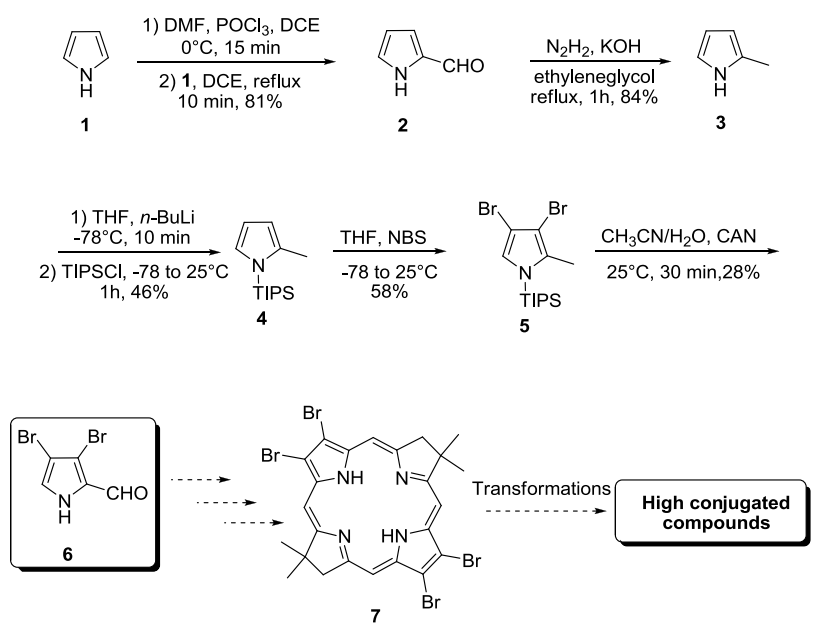

Scheme 1. Synthetic approach for new bacteriochlorins.

\section{CONCLUSION}

The synthesis of pyrrole 6 was achieved with success and represents a great accomplishment in the synthesis of pyrroles. Hereafter, we hope to achieve the synthesis of bacteriochlorin 7. This heterocycle will serve as a good template for future functionalizations.

\section{ACKNOWLEDGEMENTS}

The authors thank FAPESP (2013/06532-4, 2012/24098-4 and 2011/13993-2), CNPq and CAPES for financial support and fellowships.

\section{REFERENCES}

${ }^{1}$ Taniguchi, M.; Cramer, D. L.; Bhise, A. D.; Kee, H. L.; Bocian, D. F.; Holten, D.; Lindsey, J. S. New J. Chem. 2008, 32, 947.

2 Huang, Y.-Y.; Mroz, P.; Zhiyentayev, T.; Sharma, S. K.; Balasubramanian, T.; Ruzié, C.; Krayer, M.; Fan, D.; Borbas, K. E.; Yang, E.; Kee, H. L.; Kirmaier, C.; Diers, J. R.; Bocian, D. F.; Holten, D.; Lindsey, J. S.; Hamblin, M. R. J. Med. Chem. 2010, 53, 4018.

${ }^{3}$ a) Kim, H.-L.; Lindsey, J. S. J. Org. Chem. 2005, 70, 5475. b) Krayer, M.; Ptaszek, M.; Kim, H.-L.; Meneely, K. L.; Fan, D.; Secor, K.; Lindsey, J. S. J. Org. Chem. 2010, 75, 1016. 